Article

\title{
Preserving the Intangible: Orthodox Christian Approaches to Spiritual Heritage
}

\author{
Alexandra S. Antohin \\ Independent Scholar, Washington, DC 20010, USA; sasha.antohin@gmail.com
}

Received: 7 April 2019; Accepted: 16 May 2019; Published: 22 May 2019

check for updates

\begin{abstract}
This article presents the ways Orthodox countries form their own discourses for heritage representation and observes how these practices interact with emerging tourism and preservation agendas. Recent history of heritage tourism in Russia and Ethiopia provides insights into how participants engage with the spiritual heritage of their Churches and the contemporary dilemmas produced when orienting towards preservation protocols that seek to safeguard heritage and make it palatable to a global audience. The Ethiopian case study of Meskel, the festival of the Finding of the True Cross, a UNESCO (United Nations Educational Scientific and Cultural Organization) intangible cultural heritage entry in 2014, is examined in order to identify key issues when spiritual heritage is situated in preservation management discourse. The discussion concludes by considering a vital component of preservation efforts contained within Orthodox Churches and proposes that indigenous approaches to the elaboration and circulation of cultural values be an essential component of heritage policies.
\end{abstract}

Keywords: cultural preservation; heritage; protection policy; UNESCO; Orthodox Christianity; context; theological discourse; tourism

\section{Introduction}

The atmosphere and aesthetics of Eastern Christian churches, from humble sanctuaries to grand cathedrals, are often epitomized through testimonies as a feast for the senses, the affective qualities of its rituals and spaces as reaching the impossible standard of materializing "heaven on earth." Above all accounts, the fabled history of Vladimir I, the 10th century monarch and later saint responsible for adopting the Orthodox faith as the official religion of the Kievan Rus', best illustrates this trope. As the legend is commonly narrated, the Prince sent emissaries to travel and investigate the various religious institutions that could suit his burgeoning empire. The delegation eventually reached Constantinople, met their emperor and patriarch, and reported back to their country:

"The Greeks led us to the edifices where they worship their God, and we knew not whether we were in heaven or on earth. For on earth there is no such splendor or such beauty, and we are at a loss how to describe it. We know only that God dwells there among men, and their service is fairer than the ceremonies of other nations. For we cannot forget that beauty." (Zenkovsky 1974, p. 67)

While the effect of being impressed, overwhelmed, and completely captured by its sensorial and material cosmos are characteristics common to Orthodox ceremonial space and action, these attributes, an Orthodox Christian would emphasize, are a result of its cultivation through prayer, devotion, and most importantly, through the Holy Scriptures. Yiannis (2003) stresses that these qualities of worship are grounded in "a canon of beauty that is compatible with the new life to which believers are called. The outstanding achievement of the sacred arts of Orthodoxy lie[d] in their brilliant and 
creative response to the requirement of this canon" (Yiannis 2003, p. 1). Following this perspective, the artistry of veneration merely reveals the world as it should be, uncorrupted, and informs techniques of glorifying God that are a driving force of contemporary Church life. As a case in point, when discussing the vision of a new diocesan church in north-central Ethiopia, the head priests voiced their intention to build a house of worship that would last as long as Lalibela, the famed rock-hewn church and recognized World Heritage site that has astounded believers and visitors alike for centuries. It is this material legacy that continues to influence their cultural contributions, in the form of sites, monuments, and social customs, with great variation across the Orthodox Christian world.

This article seeks to examine approaches to representation of Orthodox Christian heritage, drawing principally from a case study analysis of Meskel, the festival of the Finding of the True Cross, a UNESCO (United Nations Educational Scientific and Cultural Organization) intangible cultural heritage entry in 2014. The context of Ethiopia, an active participant of socio-economic development agendas, permits observing, in starker terms, several key issues impacting heritage tourism as a global trend, such as its commercialization that has privileged tourist markets over viable and sustained preservation efforts (Salazar and Zhu 2015). By paying close attention to the approaches of the two institutional domains of the Ethiopian Orthodox Church and the conventions of UNESCO, the discussion investigates the power of representation, what Samuels (2015) calls the "rhetorical edge of cultural heritage ... and its persuasive capacity to mobilize and motivate" (Samuels 2015, p. 8), in order to identify the pivotal roles that audiences and their participation play in the production and circulation of heritage.

I argue that to consider heritage as a type of touristic engagement, it cannot be interpreted exclusively as a type of commercial activity, an educational or cultural enrichment, or as a means for spiritual fulfillment or national belonging. When examined critically, heritage is a rich domain of activity by participants who continuously elaborate and circulate cultural values of their community and broader environs. I propose that Orthodox Christian Churches possess concrete methodologies, drawing from the theological and pastoral body of knowledge and practice known as "Holy Tradition," that have a direct impact on heritage objectives. The following discussion presents the ways that Orthodox countries form their own discourse for heritage representation and observes how these practices interact with emerging tourism and preservation agendas. The analysis does not propose recommendations for how heritage should be devised and communicated, nor does this commentary provide conclusive findings towards this aim. It does provide one crucial observation that can be found and teased out in Orthodox Christian contexts. Heritage is a social value due to its dynamism, its invention, made possible only through the vital aspect of participation, without which intangible heritage entries remain vague and generic designations.

\section{A History of Heritagization by Orthodox Christians}

For Orthodox societies, their national histories are inextricably linked to their Orthodox Churches. Countries with deep historical roots such as Russia and Ethiopia directly engage with the historical consequences of the Church's imprint on local and indigenous traditions as well as how national narratives are communicated. In the Russian Orthodox context, the spiritual awakening of Russians "coming back to the Church" started in the late 1980s during the perestroika period. For many, the formative spiritual journey was initiated through trips to destinations such as the Golden Ring, a collection of eight monasteries and churches northeast of Moscow, popularized as a tourist attraction in the late 1960s. These monasteries are considered historically significant examples of architectural and cultural innovations of Holy Rus' ("Holy Russia"), a period before the Church became subsumed into the imperial government structure of the 18th century. The Golden Ring circuit and its touristic appeal during Soviet and post- Soviet times demonstrates how heritage helped reframe social shifts from secular norms to heightened religious consciousness. Drevnost, a synonym for ancient Russian culture or antiquity, is commonly integrated in individual reflections of the value of Orthodox heritage sites. Encountering "ancient Russian culture" by walking the grounds of the church or observing the activities of those openly faithful—from the clergy, female monks, and babushkii (the few in 
Soviet society who were transparently Orthodox)—was an eye-opening experience for those who lived without religion. A parishioner from Magadan in the Russian Far East, recalling this phase of her Orthodox awakening, compared her initial behavior as a person entering a museum, noting how far she had come to transform her orientation to the Church and the Orthodox faith.

In the Russian setting, curiosity about spiritual heritage initiated the first steps towards deeper commitments to faith and worship, acting as a muted form of Orthodox-style proselytism. Testimonies of individuals returning to the church through exposure to Orthodox heritage as tourists effectively brings back the context of worship to religious materials that had previously been confined to museums and detached from its devotional purpose. In particular, the architecture and icons of the Church and its broader material culture functioned as a gateway for many Russians to initiate closer encounters with a lineage of devotion. Kormina (2010) touches upon the idea of antiquity as it is defined through Russian heritage tourism in ways I have just described. Here, antiquity is not merely aged, dated from a golden era. She notes how pilgrim tourists talk about namolennost, the condition of items and places that are absorbed with many prayers over generations (Kormina 2010, p. 276). This aspect of Russia's Orthodox past enlivens its history with a particular spiritual definition and longevity. This partly accounts for why many Russians can insert the keywords of "roots" and "foundations" as part of an organic connection to Orthodox Church, while in some instances being able to call themselves Orthodox atheists. Visiting Russian Orthodox heritage effectively acts as synonymous with having an appreciation of Russian history, while also functioning as an antidote to the impeding fears of a secularist society.

While it is tempting to attempt to establish historical parallels between these two countries with Soviet pasts, Ethiopia has a vastly different orientation to secularization and spiritual heritage. The 1974 Marxist-influenced revolution and seventeen-year authoritarian rule of Mengistu Haile Mariam, a period known as "the Derg", irrevocably impacted Ethiopians and their political and economic systems, though its ideological objective to install an atheistic utopic society was largely unsuccessful. In contrast, in the Russian context, early Soviet administrations strategically targeted and devastated any presence of the Orthodox Church by destroying and desecrating houses of worship and exiling and murdering clerics and believers. While there are moments in its 20th century history, such as during the Great Patriotic War (World War II) where the Orthodox Church was mobilized as a source of social unity, freedom to worship and affiliate as a believer was effectively decimated for several generations. In Ethiopia, the Orthodox Church's power was severely undercut and its autonomy revoked but large-scale attempts to demoralize the church and its members, akin to the Russian case, did not take place. Not only was the length of the Mengistu regime comparatively shorter to the Soviet Union's seven decades, its application of Marxist-Leninist doctrine followed its own Ethiopian interpretation. The Ethiopian Orthodox Church considers this period as one of protest and exile for its synod and clerical leadership, and church assembly was stigmatized though not outlawed or threatened with retribution. For instance, in certain areas, churches were founded during the Derg period, indicating that Ethiopian Orthodox Christians were never completely estranged from their Church.

A far more detrimental impact on the Ethiopian Orthodox Church that has greatly influenced heritage as a local term and the evolving bureaucratic sector has been the theft and sale of antiquities on the black market. This phenomenon increased during the Derg period due to the economic hardships experienced across the social spectrum in Ethiopia. There are several reasons why the Ethiopian Orthodox Church would be an appealing target for collectors. Ethiopia is distinguished as one of the earliest Christian churches, introduced through the conversion of King Ezana in the 4th century, and as a result engaged in several key trade and diplomatic exchanges with other newly Christianized empires and rulers. Over time, as Christian Churches began to canonically schismatize into Eastern and Oriental categories, the most monumental for the Ethiopians being the Council of Chalcedon in 451, the Ethiopian Orthodox Church began to experience its own internal renaissances of Christian culture that marked them as distinct from their Orthodox "cousins" in Egypt and Syria. These historical movements had direct implications for the development of the Church's prized material heritage and 
hence for its vulnerability and security in the chambers and store houses of monasteries and churches. The Ethiopian church was responsible for retaining translations of scriptural texts and theological interpretation long lost in other Church traditions, one famous example being the Book of Enoch. Icons and crosses crafted in aesthetic traditions that have few specimens in the world are another example of items that found themselves in private hands. The crisis of stolen church treasures can be exemplified through the public uproar over the temporary disappearance of the prized cross from the Lalibela church complex, a World Heritage site, which was smuggled out of the country by an art collector and provoked a reaction of deep mourning by the townspeople (van Beurden 2001). This incident also demonstrates a greater social consciousness and articulation of valuing material culture as national heritage. Monasteries are a type of museum for cultural wealth and national identity, and the fight to protect them is itself a moral discourse. These developments serve an objective similar to what was described in the Russian case of heritage tourism: The church and faith was deployed as a domain that responds to the threat of social and historical shifts.

The Ethiopian Orthodox Church's response to the global appeal and vulnerability of its material culture has been to systematically catalogue and register historical artifacts and liturgical items and to display these collections to the public via museums within church compounds. These museums follow a familiar format, with glass cases and item labels that correspond to displays such as priest vestments, royal regalia, clerical paraphernalia (e.g., censers, processional crosses), copies of illuminated manuscripts, and liturgical books. Prior to this policy change, these items were stored inside the inner sanctum of the church, accessible only to the clergy, or in adjacent storage houses that were opened for special guests or tourists. During annual feast days and occasions, these items have important ceremonial uses and represent the few occasions where the general public has access to these items. However, the materials' liturgical context initiates a regime of reverence from worshipers that stipulates no actual touching, handling, or viewing of these items, in stark contrast to the transparency of these items' place in the museum. The additional practice of covering holy books in liturgical cloth as worshipers kiss-venerate these items further establishes how fundamentally divergent the norm of the museum display case is for Ethiopian Orthodox Christians. The policy of establishing museums as a safeguard against unauthorized acquisition of church treasures rejects the typical thesis of museums as secular spaces. On the whole, Ethiopian Orthodox perspectives do not interpret these spaces as diminishing these items' sacred qualities.

The growth of church museums is part of a broader trend of Orthodox Church administrations in Russia and Ethiopia embracing more public-facing roles. This development stems from the need to generate more creative funding streams to support their pastoral and charitable activities, ranging from church expansion projects to public health and services (Caldwell 2004; Hermann-Mesfen 2012; Zigon 2011). Sustainable revenue created by these museums requires fundraising campaigns that in turn allow local churches to expand their administrative infrastructures. Furthermore, an industry of media products, in particular video programming that broadcasts on television and is made available for purchase, effectively codifies the national value of Orthodox Christian heritage through profiles of monasteries and churches and their origin stories. This process of formatting heritage for public consumption often initiates new realities of emergent audiences and interest groups. Berliner's examination of Luang Prabang, Laos (Berliner 2012), a royal and religious capital dating back to the 14th century, outlines the various groups entangled in its preservation, such as UNESCO experts, foreign tourists, expatriates, and Lao elites from the diaspora. While each of these players develops a particular nostalgia of the ancient past, there is an ultimate coalescing and reifying of practices, geography, and imagery that is in turn used by tourist and business sectors (Berliner 2012, p. 782). In Orthodox Christian spheres, in addition to domestic touristic activities that reach their peak during seasons of pilgrimage and feast days, there is an extensive network of Orthodox "diaspora" devotees living abroad who are targeted as influential benefactors for church financial support. The last dominant group are visitors who are foreign to the Orthodox faith. Since materials produced by the Church are not commonly translated into English, options for commercially participating as a tourist are 
typically reserved for purchasing Orthodox memorabilia at souvenir shops such as crosses of various sizes and small icons. Unlike the Russian Church that holds a tighter control over the production of these religious items, in Ethiopia these items can be manufactured independently from the Church's permission, though it is typical that the sale of these items occurs outside church compounds and near tourist shop districts.

These internal developments of classifying Orthodox culture as national heritage present ideal conditions for making the Church a suitable player in tourism activities. Additionally, several more external factors have influenced the patterning of heritage preservation sectors in contexts such as Ethiopia and Russia. One appropriate parallel is the presence of development discourse that emerged from the economic and historical circumstances of isolation that both Russia and Ethiopia endured. It is important to underscore that socio-economic development practices occurred under vastly different social conditions, policy approaches, and outcomes, but the framing of Orthodox Christian societies as being opened up to the world through increased economic and cultural exchanges has been a powerful rhetoric that influenced international curiosity and support via activities such as tourism. Positioning tourism activities as a form of socio-economic development also permits interpreting the promotion of Orthodox heritage as a form of public diplomacy.

Lastly, heritage tourism, either as a landmark destination or a cluster of cultural experiences, has allowed government and social groups the ability to assert sovereign rights to cultural patrimony. Here, policy frameworks such as the Convention for the Protection of the World Cultural and Natural Heritage of 1972 by UNESCO have been instrumental in publicizing the international scope of global sites of significance, commonly associated with monuments, architectural feats, and other physical manifestations of cultural achievement. In addition to the increased visibility of these world heritage sites, its place on the registry permits applying for funding that protects the places against damage and destruction. The agency has also established new precedents for recognizing cultural value through modified definitions of heritage, such as the passage of the 2003 Convention for the Safeguarding of the Intangible Cultural Heritage. Their mandate is governed by five main domains of cultural value: "Oral traditions and expressions, including language as a vehicle of the intangible cultural heritage; performing arts; social practices, rituals and festive events; knowledge and practices concerning nature and the universe; traditional craftsmanship (UNESCO 2018, p. 5)." With this expansive scope of what constitutes "heritage" and the institutional legitimacy that UNESCO confers, marginalized groups are better equipped to argue for greater political rights and social protections.

Despite the clear overlap of spiritual phenomena into domains of the intangible - though Smith (2006) posits that all heritage, if defined as processes and negotiations of values, is always intangible rather than entities to be located and dated-less attention has been paid to the ways that spiritual significance shapes the character of heritage designations. To this aim, Meyer and de Witte (2013) advocate for stronger links between studies of heritage-making, dominantly located in policy and management reporting, and the study of religion. More precisely, they argue that the phenomenon of "sacralization" is an implicit process that demands to be made more explicit, by highlighting the recursive movements of heritage sites; to be rendered worthy of recognition, the qualities or essences that are valued have to be removed from their conventional context, causing a "profanization through which their initial sacrality is being lost" (Meyer and de Witte 2013, p. 277). Similar to Berliner's emphasis on the multiple nostalgias that arise from heritage-making (Berliner 2012), observing the "concrete acts of selecting, setting apart, designing, fashioning and inscribing cultural forms as heritage" (Meyer and de Witte 2013, p. 280) allows for deeper engagements with the politics of authenticating living traditions as local, national, and even global objects of patrimony. To push this proposal further and towards an Orthodox Christian orientation to material religion, the term "intangible heritage" provides a suitable framework of comparison between the policy narratives and its translation and implementation in participants' experiences of heritage. By considering this corollary of intangible and spiritual, I propose to investigate how representations of heritage are directly influenced by the frameworks of UNESCO policy conventions and religious institutions such as the Orthodox Church. 
The following discussion will focus exclusively on one case of intangible heritage as codified in Ethiopia in 2014 and will illustrate the interpretive terrain covered by these two approaches. Ultimately, the analysis of the various applications of heritage will permit understanding how religious institutions blend and aggregate these discourses for their own political and administrative priorities and aims.

\section{Representing the Intangible}

In 2013, UNESCO ratified the proposal of the Ethiopian government's Ministry of Culture and Tourism to recognize the holiday of Meskel as part of their international registry of intangible cultural heritage. UNESCO officially entered this Ethiopian Orthodox festival as part of its registry, citing its ritual features as well as the social harmony that the feast inspires, "an occasion for Ethiopians to promote their spiritual life through reconciliation, social cohesion and peaceful coexistence ("Commemoration", UNESCO 2019a)." The casefile for the Meskel nomination consists of signed petitions circulated by the three regional and local level governmental departments of Culture and Tourism and the Head Office of the Ethiopian Orthodox Tewahedo Church that advocate for its inclusion on the registry. In addition to petitions and procedural documents, its official registry webpage ("Commemoration", UNESCO 2019a) features a slideshow of images and a video file that documents the duration of the Meskel festivities. This is a standard template for the intangible cultural heritage entries, indicating how the use of media provides an alternative language of persuasion in ways texts cannot. The justification narratives that accompany the nomination file highlight the issues affecting heritage sectors as discussed so far. The theme of touristic marketability and its attractiveness to development, both as a form of economic activity and by the ways it promotes certain social values, is readily apparent. References to social roles as described through the preparation activities assigned to mothers, children, and the patterns of local cooperation fostered by men on the holiday (Nomination file No. 00858: Consent of Communities, UNESCO 2012, pp. 3-4) echo a common development rhetoric of social integration. In the two hundred and eleven word summary text of the Meskel entry, a short explanation of the main purpose and ritual features of the commemoration is presented-a celebration of the finding, or "exaltation" as defined in the Orthodox Christian calendar, of the True Holy Cross of Christ-and concludes by highlighting how the festival signals a time of migrant flows between urban and rural, when family reunions and conflict resolution are facilitated, and an exchange of ideas and commerce is heightened and promoted. These features of Meskel as a form of intangible heritage demonstrate how the language of cultural preservation policy produces key persuasive narratives of cultural and social values.

Emphasizing Meskel as an indigenous tradition is another crucial way that Ethiopian cultural institutions configure these policy frameworks into their cultural forms and history. The first community consent document featured in the petition file is the Kembata-Tambaro Zone's Culture, Tourism and Government Communication Affairs, where they present the case for why their region has been instrumental in the development of this holiday. Given the explicit religious character of this holiday, the effect of placing the influencing force of the Kembata people at the forefront is surprising, in effect suggesting an equivalency between how the Kembata, a relatively small ethnic group, celebrate this cultural tradition and the broader socio-political presence of the Ethiopian Orthodox Tewahedo Church, which claims approximately $48 \%$ of a population of approximately 100 million. In the heritage policy context, such a corollary is made possible and in fact makes Meskel eligible to fit the UNESCO criteria, as organized religions cannot be nominated for inscription ("Frequently Asked Questions", UNESCO 2019b). The Intangible Cultural Heritage criteria as they are applied to the Meskel entry acknowledge its "spiritual rewards" ("Commemoration", UNESCO 2019a) as part of its domains of recognition but can also be interpreted as diverting its primary reference point away from the Ethiopian Orthodox Church.

Based on how Meskel has been represented in justification documents for its inclusion on the registry, several conclusions can be drawn, namely the de-emphasis on religious worldview and the devotional importance and atmosphere that arguably are central to understanding the cultural value of this holiday. Existing categories of heritage, referred to by Ethiopians as "qers", connoting relic and 
treasure simultaneously, provide one approach for illustrating the depth of heritage that typically has multiple material essences at play. Meskel, as an Orthodox Christian holiday, is most fundamentally about the redemption that is contained in the Cross and the salvific reality of Christ's crucifixion. The holiday also relies heavily on the history that continues after this foundational event for Christianity and commemorates the discovery of the Cross and how a piece of it made its way to Ethiopia in the 15th century. The relic is housed on a four-cornered mountain that many interpret as fitting the shape of a cross and is an item as closely guarded as Ethiopia's most cherished holy item, the Ark of the Covenant. Meskel is also codified as qers through the Meshafe Tefut, a "hagiography of the relic" that describes the extraordinary journey of the Cross from the Church of Alexandria to Ethiopia. Qers, therefore, is a comprehensive understanding of heritage as it impacts various material domains and temporalities. It also enables one to envision the "spiritual benefits" of Meskel with more precision by relating the spiritual material to its liturgical and devotional context.

As the history of heritagization by Orthodox Christians placed a heavy premium on its material and ritual culture, in similar fashion, a defining component of Meskel is its bonfire festivities. A cursory examination of how it is prepared and ritually centered provides some conclusions of its social significance. For example, the aesthetics of arranging the freshly-cut grass that surrounds the bonfire or demerra and the yellow seasonal flowers are the aspects that tie the holiday to its significance as a time of auspiciousness and renewal and serve as Meskel's iconic visuals. The ritual praxis of Meskel also demonstrates the materialization of intangible heritage, in this case a holiday, as a form of commemoration of various intersecting histories. Principally, the bonfire is a recreation of an episode in 4th century Constantinople, when Queen Eleni, mother of Emperor Constantine, vowed to find the cross of the Crucifixion. After half a year of excavation, it was found buried under a garbage heap, thereby serving as an exemplary episode of the triumph of the Christian faith during a time of great persecution. Furthermore, it serves as a legitimating moment of early Christian history, given that the Queen Mother was influential for converting her son, thereby ushering in a broader acceptance and institutionalization of the religion across the Byzantine Empire. The narrative provenance of demerara's ritual praxis is based on the instruction of a holy man to use the smoke signals of a fire to lead to the direction of the hidden cross. This detail is featured prominently in popular retellings of this holiday as well as in pageant-style presentations of Queen Eleni during the Meskel ritual activities that precede the burning of the bonfire. As a contemporary presentation of Christian heritage, the bonfire performs an archetypal function of an origin rite based on historical events that have transformed into categories of "archaic spirituality" (Eliade 1954). This material component of intangible heritage as a form of local and global history exemplifies why Meskel receives such wide-spread social significance and adherence among Ethiopians, a country that positions its Christian history as a central narrative of its exceptionalism, regardless or in spite of its composition as a multi-religious nation-state.

It is worth noting that the obvious contrasts between the heritage approaches of these two institutions reflect the priorities of their intended audiences. Ultimately, the UNESCO inscriptions facilitate cooperative relationships on inter-and intra- governmental levels and with foreign entities seeking to engage in alternative diplomacy in the form of cultural preservation work. Additionally, a result of the intangible cultural heritage criteria in the case examined here indicates that justification narratives are vague and broad in order to fulfill the convention's commitment to promote values of bridging cultural differences and common connections of "society at large" ("What is Intangible Heritage?", UNESCO 2019c) as well as to remain secularly-focused. However, the removal of its internal development of the holiday displaces several key components, namely the role of participants in communicating and contributing to its value as heritage. I do not maintain that it is imperative that context be determined by religious domains or discourse, as UNESCO's Dive into Intangible Cultural Heritage! demonstrates. This interactive online tool, funded by the Kingdom of the Netherlands, invites users to engage with the constellation of nearly 500 living heritage elements arranged by concept (e.g., wood, costumes, oral tradition, craft workers as a sample) and through categories such as biomes and natural resources and the five domains of the Intangible Heritage Convention, hence 
generating search results based on individually-inputted criteria. This strategy of making policy a dynamic resource through which individuals can make connections to social issues and experiences is a step closer to envisioning intangible heritage as an integrated human phenomenon. What the UNESCO framework is less equipped to demonstrate is processes of cultural valuing that take place. For religiously-rooted concepts such as spiritual heritage, this factor can be more readily identified as devotee expressions and their regimes of reverence that are contained within Orthodox Christian ideas of Holy Tradition. I propose that without attention to expanded conceptions of heritage, the perpetuation of culture is both de-emphasized and in effect made static for the sake of heritage preservation aims.

\section{Considering Holy Tradition, a Heritage Framework for Orthodox Christians}

To envision how devotional praxis can behave as a form of cultural preservation, we return to themes common to global Orthodox Christianity and seek insights from their approaches to spiritual heritage. Local terms that describe heritage, such as qers in the Ethiopian context, fit neatly within the discourse on "Holy Tradition", a term dominantly represented by Greek and Russian Orthodox scholars who tend to be referenced more by Euro-American audiences. Within Orthodox Christian theological understanding, Holy Tradition is a compendium of teachings from the time of the Christ's disciples and is regarded as an uninterrupted continuum since the establishment of the Christian church. This idea benefits from historical authority that dates back centuries to the Fathers of the Church, anywhere from 325 to 787 depending on the branch of Christianity in question. Holy Tradition is a formalized body of knowledge as well as the techniques of accessing and engaging with it. Vladimir Lossky refers to it as "the unwritten customs ... necessary for understanding the truth of the Scripture ... the sign of the Cross, baptismal rites, blessing of oil, eucharistic epiclesis, the custom of turning towards the east during prayer and that of remaining standing on Sunday and during the period of Pentecost." (Lossky 1974, p. 147). Spiritual heritage venerated by Orthodox Christians as tourists and pilgrims, such as ancient monasteries, churches, and artifacts from those periods, is grounded in this conceptual framework that asserts that all such earthly manifestations are a result of divine revelation.

Arguing that devotional engagements with Church life, practice, and discourse are a continuation of a legacy of co-production of Holy Tradition is a more challenging claim to make, yet a vital component of studying Orthodox Christian societies, which are continuously aiming to converse and remain consistent to their faith and Church. Pop (2011) outlines the contentious substance of the debate, mainly the binary relationship between "human traditions" and "divine revelation," which he argues is "a confrontational space of argumentation and reasoning," the zone of the "Orthodox complex space" (Pop 2011, p. 104). The encompassing character of Holy Tradition facilitates a secure position of defense for Orthodox Christians, a shield against wild, undisciplined interpretation. This is important to underscore: Orthodox Christians pride themselves in their consistency and loyalty to their original sources (Bandak and Boylston 2014). Remaining true to a core body of knowledge and liturgical practice credibly defines Orthodox Christianity as belonging to the "one, true, holy and apostolic Church." Holy Tradition, then, is a container that bundles the standardized knowledge and practices that Orthodox Christians regard as foundational to their definition and orientation as members of the Church. It is this "complex space" that enables identifying the mechanisms that install value for spiritual heritage through veneration.

Holy Tradition inspires a set of approaches to veneration that provokes commitments and sentiments that animate heritages, tangible and intangible. Ethnographic works on devotees' attentive reading of the Church Fathers' teachings as a way to enliven a lost but not forgotten period of Orthodox saints of Britain (Carroll 2015) and the individual devotions of striving and modeling after moral exemplars (Naumescu 2018) serve as examples of how Holy Tradition governs practical considerations of spiritual heritage, local or otherwise. Situating Meskel as a part of Holy Tradition demonstrates how local value-making is elaborated and identifies a fundamental function of keeping heritage sites and values dynamic and relevant in contemporary terms. I propose considering pilgrimages as an 
activity that demonstrates this thesis most appropriately, coupled with the reality that domestic and secular tourism is still a novelty for many Ethiopians. In particular, the popularity of the Gishen Mariam pilgrimage, a major Orthodox Church holiday that follows Meskel, illustrates how devotional engagement drives heritage-making as a contemporary process. Here, Roy Wagner's ideas on how culture develops as human innovation (Wagner 1974), what he synthesizes as a blending of conventional and nonconventional associations, the "interplay of invention and convention" (Wagner 1974, p. 45), are a useful anchor for conceptualizing change within tradition. This interplay is the complex space that we observe in everyday religious practices of Orthodox Christians via the veneration of divine revelation on earth, manifest in material and sensory forms such as icons, gestures, places, and liturgically potent time. Therefore, the complex space of Gishen is founded on historical events of several temporalities-linking 4th century Queen Eleni of Constantinople to the 15th century devout king who requested the relic from the Church of Alexandria as a gift of Ethiopian military cooperation-and continues to flourish through centuries of worship. I contend that this is an integral essence of heritage central to the Orthodox Christians' sense of themselves within their Church's history.

As already explained, the commemoration of Meskel represents a key moment in global Orthodox Christian history, as well as a series of Ethiopian social customs of cooperation and unity, attributes that marked it as "heritage" codified by the Church and through new institutions such as UNESCO. The circumstances of the Cross' arrival to Ethiopia, celebrated as a separate feast day in late September though storied and significant for Church history and liturgical praxis, will not be outlined here. Instead, it is the activities of the celebrants, and specifically their conceptualizations of sacred place and time, supported by the Cross' location on the remote mountain location of Gishen, that are salient for proposing how the domain of Meskel extends to new contexts and inspires heritage values. It is popular for pilgrims to circulate and socially co-produce narratives of Gishen's miraculous essences, part of a well-established social practice of narrative retellings of local spiritual history (Antohin 2017). The relic's presence accounts for the belief that the air and water of Gishen heals spiritual and bodily conditions, and its sacred qualities are confirmed by the shape of the terrain, a four-sided mountain plateau. In addition to sharing the events of the various spiritually potent components of participation as a Gishen celebrant-camping out on the hallowed grounds, participating in the liturgical programs and hymns, traversing the mountain's cross-shaped corners, and most importantly, fulfilling a vow - the stories of near-death experiences are equally important towards contributing to the sacred character of the place. Treacherous road conditions and fateful obstacles of arriving at the mountain are not only dramatized in episodic detail by Gishen pilgrims, typically on their repeat visits, but also in memorabilia, the equivalent of tourist souvenirs. DVDs and posters that feature vehicles and passenger buses dangling from the precipice verify the miraculous essences of Gishen and are part of the contemporary media created by pilgrims.

Observing how heritage experiences proliferate into traditions, stories, practices, media, and other participant outputs can achieve several objectives. Regarding the analysis presented here, the Gishen pilgrimage and its specific temporal and material linkages to the Meskel festival demonstrate how one heritage element reflects a broader framework of spiritual knowledge as contained within Holy Tradition. In another project of comparative Orthodox Christian materiality, Keane (2014) focuses on controversies surrounding lay veneration of icons and relics and synthesizes a methodology for continuously confirming Orthodox Church doctrine and dogma, though an interrelation of "institutions (such as priesthoods, councils, liturgies, laws), popular practices (which can including anything from quietist piety to carnivalesque celebrations, from the use of amulets to pilgrimages, from visionary upwelling to private magic), and scriptures" (Keane 2014, p. 320); this last pillar being the ruling principle, by believers, for binding the paradoxes and potential volatility of popular practices, a domain acknowledged somewhat begrudgingly by ecclesiastical authority. Concurrent with its higher-order discourse, the customs, behaviors, and other activities that can be bracketed as regimes of veneration interact with conventional associations of the Cross as a part of global and local history. Distinguishing these engagements as complementary discourses of social values provides concrete domains to observe 
how heritage can facilitate elaboration, an essential quality of its dynamic affective potential. Even though the domain of spiritual heritage implicates participation from those religiously-motivated, I contend that heritage preservation policies demand the ability to create relationships with the value being ascribed.

This discussion has left out how engagements with spiritual heritage, whether rooted as Orthodox Holy tradition or through UNESCO frameworks of cultural preservation, have helped support ideologies of ethnic politics. Here, the post-Soviet history of Russia and its quest for religious re-definition as outlined earlier in this article returns with greater contemporary relevance. Scholarly analysis of the role of monumental churches, such as the Cathedral of Christ the Savior in Moscow, and the outcomes of tapping into restorative nostalgia of cultural and historical achievements (Haskins 2009) has served as the early signals of a more aggressive mobilization of religious institutions in the Russian Orthodox geographic sphere. From the annexation of Crimea in 2014 and now the departure of Ukraine to form its own autocephalous church, evidence of shared spiritual heritage has effectively been weaponized to serve the divergent geo-political interests of these two nations. To illustrate this trend, once again the spirit of Vladimir the Great enters the frame. The site of his baptism near the modern-day city of Sevastopol, subsequently also the location of the UNESCO-inscribed ancient ruins of a Greek city from the 6th century B.C., has been declared a national heritage site by Russia, a place of pilgrimage intended to rival Mount Athos (Oliphant 2015). This singular incident serves as another example of the enduring effectiveness of heritage frameworks to signify the ever-shifting field of values and perspectives for representing the material past that will serve to articulate a Russian Orthodox vision of encompassment that is global in scope and ambition.

\section{A Coda for Endangered Heritage}

The discussion has strayed away from providing recommendations, despite a critical analysis of how frameworks such as UNESCO's registry of intangible cultural heritage have a limited ability to provide a participant context for heritage engagement, a crucial missing component that is required for cross-cultural appreciation and value-making to take place. This concern for reforming practices and the concepts that inform them is echoed consistently in critique literature from scholars (Meskell 2013; Samuels 2015) focused on precarious preservation conditions, particularly pertinent in regions such as sub-Saharan Africa. The critical issue of making space for local actors is made by Abungu (2016) for the management of UNESCO World Heritage sites:

“Heritage professionals, site managers and heritage activists have to start thinking beyond their spaces of responsibility to ask what best practice is. They must recognize that exclusion of community voices from World Heritage sites, the tendency to treat World Heritage as a prestige phenomenon rather than a functional asset that can improve the lives of communities, and the over-centralization of decisions on World Heritage, left in the hands of the government apparatus, can be a threat to balanced and sustainable use and protection". (Abungu 2016, p. 15)

These observations can similarly be applied to the challenges of preserving intangible heritage, which by its very definition is often considered an elusive and vague category. Commentary produced by UNESCO acknowledges this reality and considers the "impact of inscription" of the nearly five hundred elements as a means of countering this critique ("Frequently Asked Questions", UNESCO 2019b). How these inscriptions impact the local landscape of heritage management will remain an unresolved limitation for how to mobilize their policy frameworks towards the objectives of preservation as a multi-party and indigenous-led endeavor.

Funding: A portion of this research was conducted as part of a doctoral dissertation fieldwork and received funding support from the Central Research Fund (University of London) and the Department of Anthropology, University College London. 
Acknowledgments: This article developed out of several presentations and case studies central for this discussion. I would like to acknowledge the feedback received from the panel participants of "Turning East: Contributions from Eastern Christianity to Negotiating Inter-Christian Engagement, Ethnic Diversity, and Cultural Creativity" at the 2017 American Anthropological Association Annual Meeting. Special thanks goes to Vlad Naumescu, the discussant, for incisive comments that helped the development of this analysis. I would also like to thank the editorial team at Jugaad: A Material Religions Project (jugaad.pub), where an earlier version of this research appears.

Conflicts of Interest: The author declares no conflict of interest.

\section{References}

Abungu, George Okello. 2016. African heritage and its sustainable development. World Heritage Review 82: 6-15. Antohin, Alexandra. 2017. Plotting "Holy Tradition in Ethiopian Orthodox Theological Discourse". In The Blessing of Enoch. Edited by Philip Esler. Eugene: Wipf and Stock.

Bandak, Andreas, and Tom Boylston. 2014. The 'Orthodoxy' of Orthodoxy: On Moral Imperfection, Correctness, and Deferral in Religious Worlds. Religion and Society: Advances in Research 5: 25-46. [CrossRef]

Berliner, David. 2012. Multiple nostalgias: The fabric of heritage in Luang Prabang (Lao PDR). The Journal of the Royal Anthropological Institute 18: 769-86. [CrossRef]

Caldwell, Melissa L. 2004. Not by Bread Alone: Social Support in the New Russia. Berkeley: University of California Press.

Carroll, Timothy. 2015. An Ancient Modernity: Ikons and the Re-emergence of Orthodox Britain. In Material Religion in Modern Britain: The Spirit of Things. Edited by Timothy Willem Jones and Lucinda Matthews-Jones. New York: Palgrave Macmillan.

Eliade, Mircea. 1954. The Myth of the Eternal Return. Translated from the French by Willard R. Trask. New York: Pantheon Books.

Haskins, Ekaterina V. 2009. Russia's Postcommunist Past: The Cathedral of Christ the Savior and the Reimagining of National Identity. History \& Memory 21: 25-62.

Hermann-Mesfen, Judith. 2012. L'Implication Du Christianisme Ethiopien Dans La Lutte Contre Le Sida: Une Socio-anthropologie de la 'guerison'. Ph.D. Thesis, Aix-Marseille Université, Marseille, France.

Keane, Webb. 2014. Rotting Bodies: The Clash of Stances toward Materiality and Its Ethical Affordances. Current Anthropology 55: 312-21. [CrossRef]

Kormina, Jeanne. 2010. Avtobusniki: Russian Orthodox Pilgrims' Longing for Authenticity. In Eastern Christians in Anthropological Perspective. Edited by Chris. M. Hann and Hermann Goltz. Berkeley: University of California Press.

Lossky, Vladimir. 1974. Tradition and Traditions. In In the Image and Likeness of God. Edited by John H. Erickson and Thomas E. Bird. Crestwood: St. Vladimir's Seminary.

Meskell, Lynn. 2013. UNESCO's World Heritage Convention at 40: Challenging the Economic and Political Order of International Heritage Conservation. Current Anthropology 54: 483-94. [CrossRef]

Meyer, Birgit, and Marleen de Witte. 2013. Heritage and the sacred: Introduction. Material Religion 9: $274-80$. [CrossRef]

Naumescu, Vlad. 2018. Becoming Orthodox: The Mystery and Mastery of a Christian Tradition. In Praying with the Senses Contemporary Eastern Orthodox Spirituality in Practice. Edited by Sonja Luehrmann. Bloomington: Indiana University Press.

Oliphant, Roland. 2015. Putin Promises Protection for Ancient Crimea Ruins. The Telegraph, August 2. Available online: https://www.telegraph.co.uk/news/worldnews/vladimir-putin/11778965/Putin-promises-protectionfor-ancient-Crimea-ruins.html (accessed on 10 May 2019).

Pop, Simion. 2011. Eastern Orthodox Christianity as Anthropological Object: Conceptual and Methodological Considerations. Studia Ubb Sociologia 56: 93-108.

Salazar, Noel B., and Yujie Zhu. 2015. Heritage and Tourism. In Global Heritage: A Reader. Edited by Lynn Meskell. Chichester: Blackwell.

Samuels, Kathryn Lafrenz. 2015. Introduction Heritage as Persuasion. In Heritage Keywords: Rhetoric and Redescription in Cultural Heritage. Edited by Kathryn Lafrenz Samuels and Trinidad Rico. Boulder: University Press of Colorado.

Smith, Laurajane. 2006. Uses of Heritage. London: Routledge.

UNESCO. 2012. Intangible Cultural Heritage. Nomination file No. 00858: Consent of Communities. Available online: https://ich.unesco.org/doc/download.php?versionID=19811 (accessed on 27 March 2019). 
UNESCO. 2018. Basic Texts of the 2003 Convention for the Safeguarding of the Intangible Cultural Heritage. Available online: https://unesdoc.unesco.org/ark:/48223/pf0000265942 (accessed on 20 March 2019).

UNESCO. 2019a. Commemoration Feast of the Finding of the True Holy Cross of Christ. Available online: https:// ich.unesco.org/en/RL/commemoration-feast-of-the-finding-of-the-true-holy-cross-of-christ-00858 (accessed on 1 April 2019).

UNESCO. 2019b. Frequently Asked Questions. Available online: https://ich.unesco.org/en/faq-00021 (accessed on 20 March 2019).

UNESCO. 2019c. What Is Intangible Heritage? Available online: https://ich.unesco.org/en/what-is-intangibleheritage-00003 (accessed on 27 March 2019).

van Beurden, Jos. 2001. A Holy Cross and the Necessity for International Conventions. Culture without Context 9. Available online: https://raffickingculture.org/publications/culture-without-context-2001-issue-9cambridge-mcdonald-institute-for-archaeological-research/ (accessed on 8 May 2019).

Wagner, Roy. 1974. The Invention of Culture. Chicago: University of Chicago Press.

Yiannis, John. 2003. Orthodox Art and Architecture. Greek Orthodox Archdiocese of America. Available online: http://imperobizantino.it/documenti/Orthodox\%20Art\%20and\%20Architecture.pdf (accessed on 8 May 2019).

Zenkovsky, Serge A., ed. 1974. Medieval Russia's Epics, Chronicles and Tales. New York: Dutton.

Zigon, Jarrett. 2011. HIV Is God's Blessing: Rehabilitating Morality in Neoliberal Russia. Berkeley: University of California Press.

(C) 2019 by the author. Licensee MDPI, Basel, Switzerland. This article is an open access article distributed under the terms and conditions of the Creative Commons Attribution (CC BY) license (http://creativecommons.org/licenses/by/4.0/). 